PARITY AND PRESTIGE IN ENGLISH SECONDARY EDUCATION REVISITED

Gary McCulloch

Address for correspondence:

Professor Gary McCulloch

Brian Simon Professor of the History of Education

Institute of Education

University of London

20 Bedford Way

London

WC1H OAL

Email address: g.mcculloch@iioe.ac.uk 


\section{PARITY AND PRESTIGE IN ENGLISH SECONDARY EDUCATION REVISITED}

Olive Banks' work Parity and Prestige in English Secondary Education (Banks 1955) was a major contribution to the literature on the historical development of secondary education. This paper analyses the nature of this contribution, assesses Banks' approach to the history of education in relation to the historiography of the past half-century, and considers the enduring significance of the themes involved for an understanding of English secondary education.

\section{Sociology, history and secondary education}

A number of prominent twentieth-century sociologists of education made notable contributions to the history of secondary education. These included the classic work of the French sociologist Emile Durkheim in the early part of the century, and the research of A.H. Halsey in Britain from the 1950s onwards. In his lectures on the formation and development of secondary education in France at the University of Paris, Durkheim insisted on the importance of understanding historical traditions in order to appraise contemporary dilemmas. He surveyed the role of the early Church, the development of cathedral schools and cloister schools, Charlemagne, the influence of Alcuin, the teaching of grammar and the origins of the universities, before moving on to the Renaissance, and then the Jesuits, culminating in the French Revolution (Durkheim 1938/1977). Halsey's emphasis was on the relationship between education and social mobility, initially with 
detailed reference to the English grammar schools and subsequently developing an analysis of intergenerational change. His doctoral thesis, completed at the University of London in 1954, examined the importance of the grammar schools as the gateway to the universities and middle class professions. It documented their unprecedented expansion between the Education Act of 1902 and 1939 through a case-study based in south-west Hertfordshire, and proposed that the Education Act of 1944 had further increased equality of opportunity and social mobility (Halsey 1954). However, his later work was more equivocal and highlighted the capacity of education 'not to create but to recreate society, not to form structures of social life but to maintain the people and the skills that inform these structures' (Halsey 1978, p. 133; see also e.g. Halsey et al 1980). This more pessimistic emphasis has tended to inform more recent sociological accounts of social class inequality and disadvantage in relation to secondary education (e.g. Breen 2005, Gray 2005).

The work of Olive Banks deserves full recognition alongside these other significant sociological excursions into the history of secondary education. Her contribution was based on her PhD thesis, completed at the University of London the year before Halsey's in 1953 (Banks 1953), and which she developed into published form as Parity and Prestige in English Secondary Education (Banks 1955). This constituted a chronological treatment of the English grammar school between 1902 and 1944, but she was clear that in her view it was neither historical nor indeed educational in its key characteristics. Banks argued that her work was sociological rather than historical because it focused on the social functions of secondary education, and the sociological implications of the 
development of the secondary grammar school (Banks 1955, p. 12). Her book in fact carried the sub-title 'A study in educational sociology', and it was included in the series of books founded by Karl Mannheim as the International Library of Sociology and Social Reconstruction. For the same reasons, she saw her domain of study as broadly social rather than as specifically educational. Her mentor was Professor David Glass of the London School of Economics, whose work was similarly framed in terms of general social problems (see e.g. Glass 1954).

Nevertheless, it did constitute an original and significant contribution to the history of secondary education in England. Banks was especially interested in explaining the persistence of the 'academic tradition' in secondary education, and identified the 'central thread' in this as 'the influence of the grammar school idea on the various forms of secondary education since 1902' (Banks 1955, p. 12). She found the strength of the grammar schools and of the academic curriculum with which they were associated as being rooted in the training that they gave for certain occupational groups. That is, in the interplay between social and educational factors, Banks identified a growing link between education and occupations as being of prime importance. It was change in the social and economic position of occupational groupings, Banks argued, that influenced the history of the grammar schools. The possession of certificates and examination success was the key to the opportunity to rise in the social and economic scale. Pressure to do so arose especially from the lower middle classes and skilled working classes such as clerks, shopkeepers, foremen and artisans. This in turn, according to Banks, explained the failure of efforts both before and since the 1944 Act to establish 'parity of esteem' 
between different forms of educational institutions such as grammar school, technical schools and modern schools. In Banks' estimation, 'If...the prestige of a school derives from the social and economic status of the occupations for which it prepares, then equality of prestige is clearly impossible between the non-selective modern schools and the selective grammar schools.' (Banks 1955, p. 252-3). The General Certificate of Education examination, like the School Certificate before it, was prized as the passport to a better job. At the same time, she argued, the strict doctrine of different types of schools with equal of prestige, preached by the Spens Report on secondary education in 1938 (Board of Education 1938) and the Norwood Report on the secondary school curriculum and examinations in 1943 (Board of Education 1943), 'could only succeed in a more equalitarian society' (Banks 1955, p. 245).

Banks therefore attributed the power of the academic tradition in secondary education not to 'the influence, sinister or otherwise, of teachers and administrators', but to 'the vocational qualification of the academic curriculum' (Banks 1955, p. 248). It was this that enabled the academic tradition to exert such pressure on all forms of secondary education. She concurred with the American social and economic critic Thorstein Veblen in his influential work The Theory of the Leisure Class (Veblen 1899/1973) that the social system was dominated by what Veblen had described as 'pecuniary emulation'. According to Veblen, the desire for wealth shaped the methods and selected the objects of expenditure for personal comfort and decent livelihood (Veblen 1899/1973, p. 39), and was especially influential in institutions of higher learning. Banks concluded that parity of esteem in secondary education was likely to remain 'elusive' while this was the case, 
and so the movement towards educational equality would be 'dependent on the social movements of our time' (Banks 1955, p. 248).

In her inaugural lecture as professor of sociology at the University of Leicester in 1974, Banks developed this point further. She proposed here that equality of educational opportunity did not lead to a more egalitarian society, but that the reverse might be the case: 'That is to say, full equality of opportunity is only possible in a society which is no longer rigidly stratified.' (Banks 1974, p. 15). This was because, as she argued, inequality in educational achievement arose not only from disparities in educational provision, but also from 'the whole way of life which distinguishes the main social classes in present-day society and which are rooted in their different opportunities for wealth, power, security and status' (Banks 1974, p. 15). This meant in turn that the development of comprehensive schools would not in itself create a less divided or stratified society, and that there was a need for general social policies rather than specifically educational ones. The school was not itself an agent of social change: 'In so far as the school is still seen as an agency for reform it is now widely accepted that this can only be on a relatively modest scale.' (Banks 1974, p. 18). Indeed, she concluded, 'changes in the educational system can be expected to have only a limited effect on social inequalities and social stratification in general' (Banks 1974, p. 19).

\section{Banks and the historiography of education}


These arguments clearly carried major implications for sociology in general and the sociology of education in particular, reflected in her influential text The Sociology of Education which was published in 1968, subsequently reprinted several times, and went into a second and then a third edition in the 1970s (Banks 1968). They also set her apart in terms of her perspective on historical developments in relation to the work of historians of education between the 1950s and the 1970s. In the first place, they stood in sharp contrast to the liberal perspective that was dominant in educational historiography in the 1950s. This approach, evident in the writings of historians of education such as Curtis (1948) and Armytage (1964), tended to portray the history of education unproblematically as a story of continual improvement and refinement led by a partnership between the education profession and the benign nation state, and promoting social harmony and increasing economic prosperity over the longer term (see e.g. McCulloch and Richardson 2000, especially pp. 36-37). Banks' analysis of the history of secondary education, with its emphasis on controversy and conflict between opposing social and economic tendencies, helped to disrupt this optimistic liberal-progressive paradigm. It thereby contributed to the early development of more critical histories of education in its broader social, cultural and economic contexts that were to become increasingly favoured from the 1960s onwards.

Yet in some respects Banks' work was also out of line with the new wave of educational historiography that emerged during this period. She was concerned with the persistence of social inequalities and political debate around education, as was also the case with the newer historians of education. She differed from many of them in that she questioned the 
idea that educational legislation, policy, theory, teachers and administrators tended to thwart educational change, and also denied that educational influences were potentially significant as a means of promoting educational and social reform. It is also notable that Parity and Prestige was not particularly interested in the factors of social class and gender in the history of education, and indeed argued that the situation facing secondary schools girls was 'in spite of certain differences, basically the same' as for boys (Banks 1955, p. 193). This was in sharp contrast with later work in this area. Since the 1960s, attention has shifted to the social class and gender differences reflected and reinforced in the secondary education of these years.

In relation to social class, most notably, Brian Simon's major study of the history of education in England included a critical examination of the social class inequalities of secondary education in the early decades of the twentieth century. According to Simon, 'Since the outset of the century the central question in the field of public education has been the nature and scope of the secondary school system, the curriculum and means of access, the implications in terms of organization and finance, the respective share in shaping developments of central and local authorities.' (Simon 1974, p. 10). He depicted an underlying conflict between, on the one hand, pressures to extend school life and to improve the quality of education for the majority of the age range and, on the other, a determination to maintain the separate and limited system of elementary education that had been established in the Elementary Education Act of 1870 (Simon 1974, p. 10). In the 1920s and 1930s in particular, he argued, an official emphasis on economy had matched an elitist ideology 'to programme secondary education only for an elite with, for 
the majority, merely ancillary provision to promote togetherness in the tasks of making capitalist industry and social relations work' (Simon 1974, p. 318).

A more recent study, by Felicity Hunt, has emphasized the importance of gender as 'a further, and even more fundamental category of social analysis' than that of class (Hunt 1991, p. 1). This work provides an account of education decision making about schooling for girls between 1902 and 1944, especially with respect to how pupil gender became an issue in educational policy over this time (see also e.g. Hunt 1984). Hunt documented the inconsistencies and ambiguities in the attitudes of the Board of Education towards secondary education for girls, and the influence exerted by the Board over the secondary school curriculum. In particular, she emphasized the significance of curricular differentiation between boys and girls in the secondary schools, arguing that this reflected and maintained male privilege in the public domain.

The combination of class and gender inequalities found in the work of Simon and Hunt supports a general interpretation, influenced by Marxist and feminist theory, that secondary education in this period was fundamentally elitist, based on entrenched social interests and ideologies, and enforced by a coterie of Board of Education officials who were, as the leading educational reformer R.H. Tawney observed, themselves drawn from an exclusive social and educational background (Tawney 1931/1964, pp. 144-45). This is a markedly different emphasis from that of Banks. Their interpretation puts the focus on the unwarranted power and influence of an unrepresentative elite group, quite unlike 
Banks' analysis which explained the continued dominance of the grammar school curriculum in terms of the occupational labour market.

There are other aspects of Banks' work that appear striking omissions looking back more than fifty years later. First, it approached the topic from a broadly national and structural perspective. It included very little local or institutional case-study material or biographical evidence, and did not attempt to set developments in English secondary education within a wider international context, or still less a global one. These are issues that have attracted greater historical attention in more recent years.

The work of Reeder, Roach and Marsden did much to highlight the local and urban dynamics of secondary education in England which had been relatively neglected in earlier research (see e.g. Reeder 1987, Roach 1991, Marsden 1987). This trend was developed further through detailed local and institutional case studies of different kinds of educational provision. Marsden for example produced an extended study of Fleet Road Board School in Hampstead, often dubbed 'the Eton of the Board schools', and its significance in the process of educating the respectable groups in society (Marsden 1991). Banks had reviewed the rise of the higher grade schools which briefly challenged the influence of grammar schools in the final decades of the nineteenth century (Banks 1955 , chapter 2), but it was left to later work, most notably perhaps that of Mel Vlaeminke, to examine local examples in detail. Vlaeminke developed a local case study of Bristol before and after the Education Act of 1902 in which she explored the characteristics of specific institutions, especially St George, Merrywood and Fairfield 
Road higher grade schools, and then the development of each of these schools under the new regime (Vlaeminke 2000, chapters 3 and 4). Other work of this kind has sought to relate educational ideals to local practice. For instance, Kevin Manton has examined the contributions of Frederick James Gould, who established a number of socialist Sunday schools and wrote lesson books for them, and Harry Lowerison, the founder of Ruskin School in Norfolk (Manton 2001). A number of local and institutional studies have also been produced as masters and doctoral theses, in a sense following the lead of Halsey's doctoral research rather than that of Banks (see e.g. Hunt 1984, Robinson 1990, Blades 2003).

Moreover, Banks did not pursue potential connections between individual and personal factors on the one hand and the social domain on the other. Biographical approaches have been further developed in the history of education over the past two decades, for example in the work of Richard Selleck and Jane Martin (Selleck 1974; Martin 2003). In relation to secondary education in the first half of the twentieth century, the instance of Cyril Norwood is especially revealing for what it demonstrates about the significance of individual lives and careers in educational change (see also McCulloch 2006a, 2007 for further details and discussion of Norwood's role and influence in this period). Norwood was a leading teacher and headteacher, and also a highly influential educational policy maker during this period, and his personal and professional sympathies culminated at the end of his long public career in the publication of the so-called 'Norwood report' on curriculum and examinations in secondary schools (Board of Education 1943). 
International currents in educational ideas and practices were also left unexplored in Banks' study of secondary education. Strenuous efforts were made in the 1930s to promote international collaboration in the development of ideals of secondary education for citizenship, for example, notably under the auspices of the New Educational Fellowship, and English educators were prominent in these discussions (see e.g. McCulloch 2007, chapter 8). A number of teachers' associations sought to encourage international solidarity and intellectual cooperation in the 1920s and 1930s (Goodman 2007). On the other hand, the ideals on which the Norwood report was based were different from the democratic and egalitarian aspirations of the American high school over the same period (see e.g. Reese 2005; Franklin and McCulloch 2007).

Thus, the agendas and interests of historians of education have diversified greatly since the publication of Banks' Parity and Prestige. It is also intriguing to note that Banks' preoccupation with the differential status of institutions of secondary education was mainly confined to education supported by the State, rather than involving the private sector or elite 'public' boarding schools. She did acknowledge that public schools still enjoyed a dominant position in the hierarchy of schools, and included a brief discussion of their role (Banks 1955, pp. 8-9). She took the opportunity to stress that public schools would not easily be abolished so long as they continued to 'minister to the needs of a stratified society' (Banks 1995, p. 245). Banks added that public schools were a greater threat to social unity than the tripartite system, 'if only because the barrier between the public schools and the maintained grammar school is deeper than that between the grammar and modern schools' (Banks 1955, p. 246), but did not pursue this further. 
The barrier between the public schools and maintained grammar schools was however worthy of much fuller discussion in the elucidation of parity and prestige in English secondary education. The divide between private and state provision has survived all the major social and political changes of the past century, and has resisted unscathed even the most determined of educational reforms (see also e.g. McCulloch 2004). Private schools, and especially the elite public boarding schools, were widely regarded as socially superior to the schools in the maintained sector. This superiority was often cultivated in a highly conspicuous fashion, marked at Eton College, for example, in school dress, talcoats, Eton jackets and Eton collars, in what one former pupil remembered as 'an ostentatious and arrogant defiance of contemporary society' (Ollard 1982, p. 12). Ronald Gurner, who had experience of teaching at both public schools and grammar schools, was frank as to the differences between them. In his view, the most telling issue was social, in that maintained schools included former elementary and working class pupils, which could lead to what Gurner described as 'contamination':

It is difficult, if you are a country solicitor or doctor of any standing, to contemplate with equanimity the possibility of your son sitting side by side with the son of your junior clerk or chauffeur - better send him to St Cuthbert's on the south coast. The fees are high, and you are not certain as to exactly what is the standard of education which that excellent residential establishment provides - but there are no board-school [sic] boys there, and in the things that matter your boy will be safe (Gurner 1930, p. 15). 
Moreover, the public schools remained fiercely resistant to any attempts at usurping their rights and freedoms.

Cyril Norwood, for example, experienced these social distinctions and political attitudes at first hand in his personal, professional and policy making capacities. In 1917, Norwood was appointed to be Master of a leading public boarding school, Marlborough College, having previously been the very successful head of Bristol Grammar School, which was in the maintained sector under the provisions of the Education Act of 1902. He was himself from a clerical and provincial middle class background, although he had been educated at Merchant Taylors' School in London, which although it was classed as a public school was also mainly a day school rather than a boarding school. His social background and grammar school experience led him to be regarded with some disdain by many of the pupils, parents and staff. The poet Louis MacNeice, who had been a pupil at Marlborough College under Norwood, later recalled in his autobiography that schoolboy snobbery was endemic during this period: 'Their conversation, when it was not shop, was infected with the social snobbery they brought from home.' (MacNeice 1965, p. 81). Norwood himself was viewed by many as being socially inferior. According to another former pupil, T.C. Worsley, Norwood's nickname at Marlborough was 'Boots', an epithet acquired 'not so much because he habitually wore them, as because they were the outward and visible sign of his not being quite-quite' (Worsley 1966, p. 40). Indeed, Worsley continued, 'He had been appointed to Marlborough from some minor grammar school and, such was the snobbery of us well brought-up children that, just for that reason, he was booed in the school hall on his first appearance' (Worsley 1966, p. 40). 
Norwood went on to become Head of an even more social elite public school, Harrow School, where he was challenged by a number of the masters and parents who associated themselves with the traditions of the school. In the 1ate 1930s, Norwood proposed uniting the private boarding schools and the state-aided system into a single national system, and was vehemently opposed. It was ironic and highly symptomatic that Norwood, who famously celebrated the 'English tradition' of education (Norwood 1929), was castigated and ultimately marginalized as a result of these pervasive social and political differences (see McCulloch 2007 for detailed discussion of Norwood's role during this period).

\section{Legacy and significance}

In conclusion, Banks' research on parity and prestige in secondary education has continuing significance and leaves a legacy for the twenty-first century in at least three respects. First, she championed a close relationship between sociology and history which deserves attention. Recent research by sociologists of education in Britain has highlighted the middle-class social and cultural characteristics of secondary education, including the detailed nuances of middle-class identities and social practices, and the ways in which middle-class families underpin the process of social reproduction that ensure the retention of social advantages from generation to generation (see e.g. Ball 2003; Power et al 2003; Devine 2004; Reay 2005). Some of this new work has shown that the insecurities of middle-class families have helped to exacerbate tensions around the use of private education and conflicts over academic and vocational curricula (e.g. 
Tomlinson 2005, p. 173). These key insights need to be related in a systematic fashion to changes and continuities in secondary education over the past century and beyond (McCulloch 2006b). Banks offers an instructive model of how to achieve this.

Second, her emphasis on parity and prestige as issues in English secondary education touched a vital and enduring theme that continues to be relevant and pervasive in the early years of the twenty-first century. Despite the spread of comprehensive education since the 1960s, issues of parity and prestige have remained highly contentious in debates around secondary education, for example in relation to selection, choice, vocational education, and partnerships between the state sector and the private sector. Despite the many changes of the past half-century, therefore, Banks' work in this area is still an important reference-point for our understanding.

Finally, Banks' research was significant in helping to indicate the social dimensions of the determinants of secondary education, and raised an important set of issues in relation to the role of the link between education and occupations. Subsequent detailed historical research has developed our understanding of the social dynamics of secondary education in the period between 1902 and 1944 in a number of directions. It remains a rich and fascinating area that will benefit from still further research. This should continue to benefit, more than fifty years on, from a study of Olive Banks' major contribution to the field. 


\section{REFERENCES}

Armytage, W.H.G. (1964) Four Hundred Years of English Education, Cambridge

University Press, Cambridge

Ball, S. (2003) Class Strategies and the Education Market: The Middle Classes and

Social Advantage, RoutledgeFalmer, London

Banks, O. (1953) 'The concept and nature of the grammar school in relation to the development of secondary education since 1902' (unpublished $\mathrm{PhD}$ thesis, London School of Economics, University of London)

Banks, O. (1955) Parity and Prestige in English Secondary Education: A Study in Educational Sociology, Routledge and Kegan Paul, London Banks, O. (1968) The Sociology of Education, Batsford, London

Banks, O. (1974) Sociology and Education: Some Reflections on the Sociologist's Role. Inaugural lecture, University of Leicester, delivered 5 February 1974, Leicester University Press, Leicester

Blades, B. (2003) 'Deacon's School, Peterborough, 1902-1926: A study of the social and economic function of secondary schooling' (unpublished $\mathrm{PhD}$ thesis, Institute of Education, University of London, 2003)

Board of Education (1938) Report of the Consultative Committee on Secondary

Education with Special Reference to Grammar Schools and Technical High Schools, HMSO, London (Spens Report)

Board of Education (1943) Curriculum and Examinations in Secondary Schools, HMSO, London (Norwood Report) 
Breen, R. (2005) Why did class inequalities in educational attainment remain unchanged over much of the twentieth century? In A.F. Heath, J. Ermisch, D. Gallie (eds), Understanding Social Change, Oxford University Press, Oxford, pp. 55-72

Curtis, S.J. (1948) History of Education in Great Britain, University Tutorial Press, London

Devine, F. (2004) Class Practices: How Parents Help their Children to get Good Jobs, Cambridge University Press, Cambridge

Durkheim, E. (1938/1977) The Evolution of Educational Thought: Lectures on the Formation and Development of Secondary Education in France, Routledge and Kegan Paul, London

Franklin, B. and McCulloch, G. (eds) (2007) The Death of the Comprehensive High

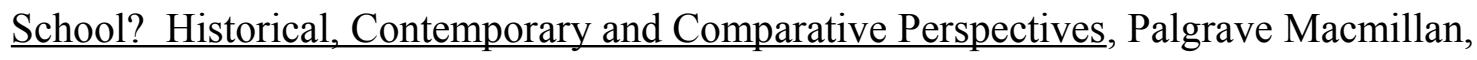
New York

Glass, D.V. (ed) Social Mobility in Britain, Routledge, London

Goodman, J. (2007) Social change and secondary schooling for girls in the 'long 1920s': European engagements, History of Education, 36/4-5, pp. 497-513

Gray, J. (2005) Is failure inevitable? The recent fate of secondary school reforms intended to alleviate social disadvantage. In A.F. Heath, J. Ermisch, D. Gallie (eds), Understanding Social Change, Oxford University Press, Oxford, pp. 73-91

Gurner, R. (1930) Day Schools of England, J.M. Dent and sons, London Halsey, A.H. (1954) 'The relation between education and social mobility with particular reference to the grammar school since 1944' (unpublished $\mathrm{PhD}$ thesis, London School of Economics, University of London) 
Halsey, A.H. (1978) Change in British Society, Oxford University Press, Oxford

Halsey, A.H., Heath, A., Ridge, J. (1980) Origins and Destinations: Family, Class and

Education in Modern Britain, Clarendon Press, Oxford

Hunt, F. (1984) 'Secondary education for the middle class girl: a study of ideology and educational practice 1870-1940, with special reference to the Harpur Trust girls' schools, Bedford' (unpublished PhD thesis, University of Cambridge)

Hunt. F. (1985) Social class and the grading of schools, realities in girls' secondary education 1880-1940. In J. Purvis (ed), The Education of Girls and Women, History of Education Society, Leicester, pp. 27-46

Hunt, F. (1991) Gender and Policy in English Education: Schooling for Girls, 1902-44, Harvester Wheatsheaf, London McCulloch, G. (2004) From incorporation to privatization: public and private secondary education in twentieth-century England. In R. Aldrich (ed), Public or Private Education? Lessons from History, Woburn, London, pp. 53-72

McCulloch, G. (2006a) Cyril Norwood and the English tradition of education, Oxford Review of Education, 32/1, pp. 55-69

McCulloch, G. (2006b) Education and the middle classes: the case of the English grammar schools, 1868-1944, History of Education, 36/6, pp. 689-704

McCulloch, G. (2007) Cyril Norwood and the Ideal of Secondary Education, Palgrave Macmillan, New York

McCulloch, G. and Richardson, W. (2000) Historical Research in Educational Settings, Open University Press, Buckingham 
MacNeice, L. (1965) The Strings are False: An Unfinished Autobiography, Faber and Faber, London

Manton, K. (2001) Socialism and Education in Britain, 1883-1902, Woburn, London

Marsden, W.E. (1987) Unequal Educational Provision in England and Wales: The

Nineteenth-Century Roots, Woburn, London

Marsden, W.E. (1991) Educating the Respectable: A Study of Fleet Road Board School, Hampstead, 1879-1903, Woburn, London

Martin, J. (2003) The hope of biography: the historical recovery of women educator activists, History of Education, 32/2, pp. 219-32

Norwood, C. (1929) The English Tradition of Education, John Murray, London

Ollard, R. (1982) An English Education: A Perspective of Eton, Collins, London

Power, S., Edwards, T., Whitty, G., Wigfall, V. (2003) Education and the Middle Class,

Open University Press, Buckingham

Reay, D. (2005) Thinking class, making class, British Journal of Sociology of Education, 26/1, pp. 139-43

Reeder, D. (1987) The reconstruction of secondary education in England, 1869-1920. In

D. Muller, F. Ringer, B. Simon (eds), The Rise of the Modern Educational System,

Cambridge University Press, Cambridge, pp. 135-50

Reese, W.J. (2005) America's Public Schools: From the Common School to 'No Child

Left Behind', Johns Hopkins University Press, Baltimore

Roach, J. (1991) Secondary Education in England 1870-1902: Public Activity and

Private Enterprise, Routledge, London 
Robinson, W. (1990) 'Breaking the elementary mould: a study of nine higher grade girls' schools under the London School Board, 1882-1904' (unpublished MA thesis, Institute of Education, University of London)

Selleck, R.J.W. (1974) James Kay-Shuttleworth: Journey of an Outsider, Woburn, London

Simon, B. (1974) The Politics of Educational Reform, 1920-1940, Lawrence and

Wishart, London

Tawney, R.H. (1931/1964) Equality, Allen and Unwin, London

Tomlinson, S. (2005) Education in a Post-Welfare Society, $2^{\text {nd }}$ edition, Open University

Press, Maidenhead

Veblen, T. (1899/1973) The Theory of the Leisure Class, Houghton Mifflin Company, Boston

Vlaeminke, M. (2000) The English Higher Grade Schools: A Lost Opportunity, Woburn, London

Worsley, T.C. (1966) Flannelled Fool: A Slice of Life in the Thirties, Allen Ross Ltd, London 